\title{
Necessity or Luxury? Sober Second Thoughts on the Chinese Gideon and Legal Aid in Criminal Cases
}

\author{
Luye Mou*
}

Many Chinese scholars advocate transplanting the American Gideon to improve the quality of criminal defense and legal aid in China. Nowadays, less than thirty percent of criminal defendants in China have counsels to represent them, and this has worsened since the year of 2012, because laws and policies have expanded the legal aid to more candidates, while the appropriations cannot keep pace with the explosive caseload. Institutional impediments also frustrate lawyers' efforts in providing effective representation, and there is no remedy for ineffective-assistance-of-counsel claims. This paper calls for a fuller understanding of the Gideon's broken promise in the US, and argues that the forces most essential to the support of the Chinese Gideon can only come from China's practice and experience.

Keywords: Gideon v. Wainwright, Legal Aid, Right to Counsel, Effective Assistance of Counsel, Legal Transplant

It is to be remembered that they are Chinese codes, to be applied to the Chinese people, to govern Chinese life. ${ }^{1}$

* Assistant Professor of Law, Zhejiang University Guanghua Law School. LL.B./LL.M. (CUPL), LL.M. (Harvard), Ph.D. (Peking). ORCID: https://orcid.org/0000-0003-3805-0313. This study is supported by the Fundamental Research Funds for the Central Universities. Special thanks go to Professor William P. Alford for his valuable suggestions in writing this article and his generous support for my studies in the US. The author may be contacted at: luye_mou@zju.edu. cn/Address: Zhejiang University Guanghua Law School, Zhijiang Road No. 51, Xihu District, Hangzhou City, Zhejiang Province, 310008, China. 


\section{INTRODUCTION}

After the Cultural Revolution, Chinese scholars took a new look at international wisdom to modernize their legal system. Many Western doctrines have encouraged abundant comparative studies since then. The introduction of a wellfunctioning legal mechanism, identification of the corresponding weakness in its system, and the suggestion of certain reforms gradually became a fashionable pattern throughout the 1990s. However, the hidden assumption underlying Western preferences and China's efforts shares an unwarranted universal value that may leave them with an impoverished understanding of comparative studies and Chinese choice. Any blind embrace of the legal conception arbitrarily forces Chinese people to fit foreign percepts of the mode of life, rather than making them fit the people they are to serve. ${ }^{2}$

The right to counsel, as recognized in Powell v. Alabama, ${ }^{3}$ Gideon v. Wainwright, ${ }^{4}$ and their progeny, ${ }^{5}$ entails that the Sixth Amendment guarantees the right to counsel for all the criminal defendants. This right was incorporated into the PRC Constitution and other basic laws in the form of legal aid decades after Powell. Legal aid was loosely defined in China, encompassing work ranging from informal consultations to free legal representation of the poor. ${ }^{6}$ In view of the US Supreme Court ("USSC")'s recent rejection of a civil Gideon in Turner v. Rogers, this paper focuses on the Gideon in criminal cases.

Chinese perception of the Gideon divides into two levels: the right to counsel and the right to effective assistance of counsel. The former has been recognized in the 1978 Constitution and 1979 Criminal Procedural Law ("CPL"), while the latter has been emphasized since the end of the twentieth century. Many scholars who are concerned about the chronically poor quality of legal aid have advocated the American-style Gideon to regulate lawyers' performance and reduce wrongful convictions. ${ }^{9}$ The Gideon seems to be extolled as a 'grand theory' that offers an ideal model to tackle legal problems. Nevertheless, the inherent dangerousness of any 'grand theory' imposes upon China an obligation to be vigilant from the outset of any comparative inquiry. ${ }^{10}$ Therefore, the key issue in this paper can be summarized as whether it is preferable to transplant Western doctrines or develop and adapt Chinese institutions and teachings. Specifically, we wonder if the Gideon is a necessity or a luxury for the criminal defense in China. ${ }^{11}$ If the answer 
is yes, what sort of the Gideon does China need?

In this research, the author will argue for a cautious attitude toward the Chinese Gideon. This paper consists of seven parts including Introduction and Conclusion. Part two will surveys two levels of the Gideon in China. Part three will review insufficient appropriation and new challenges regarding funding matters. Part four will tackle institutional obstacles to the Chinese Gideon. Part five will examine difficult and risky lawyering. Part six will discuss inadequate or inaccessible remedies for the Gideon claims. The concluding part will offer additional remarks on Western models and China's localized path.

\section{Two Levels of THe Gideon In China}

Anyone familiar with the operation of the criminal process will attest that one of the best ways to ensure its proper functioning is to invite qualified lawyers and their effective inputs. ${ }^{12}$ This conclusion has been reached by the USSC in Gideon v. Wainwright that recognized the Sixth Amendment right to counsel as a fundamental right to a fair trial. In the adversary system, lawyers are deemed essential to protect the public's interests, but this ideal cannot be realized if a poor man charged with crime has to face his accusers without a lawyer. ${ }^{13}$ For that reason, the USSC described "the right to counsel as the right to the effective assistance of counsel." "14 This doctrine has been consistently elaborated since then.

Discussions of the Gideon in China are split into two stages: the first one dates from the 1980s to the end of 1990s, when nearly all the legislation and academic resources were contributing to the "right to counsel" in criminal cases. The second stage began in the early twenty-first century when the "right to effective assistance of counsel" became a popular idea among scholars.

\section{A. Right to Counsel}

In 1978, the PRC Constitution first recognized the right to counsel. The revised Constitution in 1982, still in effect today, reaffirmed the right to counsel, and the 1996 CPL - which plays a central role in ensuring the right to counsel due to the unenforceability of the Constitution ${ }^{15}$ - set up specific rules to protect the defendant's rights. 
Following the constitutional principle of respecting and protecting human right, the 2012 CPL advances the right to counsel in five main aspects: 1) lawyers are confirmed as 'defenders' at the investigative stage; 2) there is more emphasis on the defenders' duty to challenge the police's illegal conduct; 3 ) the process is amended to facilitate the interview; 4) defenders are allowed to obtain and read case files; and 5) defenders have to maintain confidentiality over information about the case. ${ }^{16}$ Particularly, when hearing a death penalty case, the Supreme People's Court ("SPC") must listen to the lawyer's opinion if s/he files a request. All those form the basic structure of the first level of the Chinese Gideon.

In the US, approximately 80 percent of people charged with crime are poor, so that they would rely on the counsels provided by the state in different forms of legal aid. ${ }^{17}$ By the same token, the legal aid system is indispensable to the guarantee of the right to counsel of the poor in China. The former Minister of Justice, Xiao Yang, laid the foundation of legal aid in 1996: "Providing free legal assistance for the indigent can protect their basic rights, which helps build stable society and promote a booming national economy." ${ }^{18}$ To provide a support system for the 1996 CPL, the SPC and the Ministry of Justice ("MOJ") jointly released the Notice about the Legal Aid in Criminal Cases, which was the first regulation of legal aid in China and was subsequently replaced by the 2003 Legal Aid Regulations applied in both criminal and civil cases. ${ }^{19}$

Since then, China's legislature has repeatedly emphasized that the right to counsel is critical to correctly tackle the case and effectively protect the defendant's rights. ${ }^{20}$ In 2013, they released the new Legal Aid Regulations in Criminal Cases. Besides the legislation, the Chinese Communist Party ("CCP"), as the most influential organization in today's China, has expressed strong concern about the people's economic means since 2012. With strong financial support, the MOJ determined to improve the 20-year-old legal aid system, one of whose big moves was to lower the threshold and expand the number of people who can receive free legal aid. ${ }^{21}$ All those efforts have guaranteed the constitutional right to counsel, which is the first and fundamental level of the Chinese Gideon.

\section{B. Right to Effective Assistance of Counsel}

Having access to counsels does not entail indigent defendants to "an adequate 
opportunity to present their claims fairly within the adversary system.. ${ }^{, 2}$ Rather, proper criminal defense requires that lawyers should: 1) be competent; 2) offer prompt and diligent representation that protects the client's interests; and 3) productively engage with the client while exercising independent judgment. ${ }^{23}$ As the enforcement mechanism of the Gideon, Strickland defined the right to counsel in a negative way. If the counsel's performance were deficient which prejudiced the defendant, then the counsel's assistance could be deemed as defective that the conviction could be reversed. ${ }^{24}$

In China, it is much easier to expand the number of legal aid programs and lawyers than monitoring how such work is performed and how effective the work is. ${ }^{25}$ Researchers have described the role of the criminal defense lawyer within China's criminal justice system as symbolic than real. For instance, McConville showed that defense lawyers at the pre-trial stage were too passive to construct a case by going to crime scenes, tracing and interviewing witnesses or engaging in evidence collection. ${ }^{26}$ Likewise, $\mathrm{Lu}$ and Miethe found that, contrary to the image of an advocate of the defendant, no criminal defense lawyers insisted that their clients be innocent and all of them plead for leniency. ${ }^{27}$ Even in the most aggressive type of defense, lawyers merely asked the court to reconsider some mitigating factors.

Consequently, the right to effective assistance of counsel gradually becomes a point of contention in Chinese academic literature. Around 813 papers specially discussing the Gideon in at least one chapter or more have been published since the year of 2000. They mainly discussed the way to cope with Chinese issues with American experience. Yinghui Song is a pioneer who first clearly proposes the right to effective counsel in China. After referring to international conventions and general standards in Western countries, Song claimed: "The defendant has the right to counsel" entailed the idea of effective assistance, and the government must provide legal aid to ensure such a basic right. ${ }^{28}$ Another leading scholar Ruihua Chen argued that the Gideon required the higher-quality legal service and should be a goal of future legal reform. ${ }^{29}$ Unlike those moderates, Xiangde Ji wrote a series of papers to passionately support the Chinese Gideon. In his opinion, as setting up basic guidelines for effective defense was another way to improve the quality of criminal defense, China must build a comprehensive frame of the Gideon. ${ }^{30}$ It is fair to say that the second level of the Gideon is becoming more 
popular in the scholarly community.

Although Chinese lawyers have shown some interest in Western views, even the most successful criminal defense lawyers rarely talk about the second level of the Gideon. It is understandable that lawyers do not like the effectiveness prong, because it is a demanding requirement for additional work and the fiduciary duty no matter who will pay and how much they may benefit. At a minimum, this makes people have doubts when the stakeholders are indifferent, or even resistant, to a foreign ideal.

Moreover, China's legislature and judiciary are unfamiliar with the second level of the Gideon. In 2015, they launched the Trial Centralization Reform ("TCR") to build a litigation system with trials at the core, and enhance the court's ability to supervise investigative practices. ${ }^{31}$ Having realized that "a good lawyer is the best defense against the wrongful conviction," they highlighted the significance of lawyers' role and their work. Essentially, the TCR and lawyers are expected to instrumentally calm a public aghast over miscarriages of justice, rather than guaranteeing the right to counsel or a fair trial.

\section{The 1996 CPL Reform and its Lessons}

Here is an example worth recalling, which is a preface to the specific policy analysis of the aftermath of legitimizing the Gideon in China. The 1996 CPL absorbed many positive elements from the adversary system. To accommodate changes in the code, most leading scholars convinced the SPC to reform the trial by intensifying the contention between parties and weakening judge's control over the trial. The court, traditionally taking the lead in questioning witnesses and marshaling evidence, was expected to be a more impartial role as a neutral adjudicator. ${ }^{32}$ Thus, the police and the procurator must learn to accept the more aggressive role of criminal defense lawyers in challenging their work.

In the next four to five years, however, many hidden rules made formal mechanisms exist nominally. For example, as nearly all the witnesses have never been testified in court, lawyers would lack resources to compete with prosecutors who mostly dominated in the investigation and trial because judges start to take a hands-off approach to case adjudication. ${ }^{33}$ Under those conditions, criminal defense lawyers must maintain the cooperative relationship in the court, as they knew the best results for their clients could be obtained by not being 'combative' 
but being 'deferential. ${ }^{34}$ Eventually, the adversary ideal was scattered to the wind, leaving nothing more than chastening lessons in today's legal reform forums.

First, we should maintain vigilance against reforms advocated by scholars. The preparation for the 1996 CPL revision started from a small-scale academic symposium held in 1991. Two year later, Guangzhong Chen, a chair professor of criminal procedure law of China University of Political Science and Law, was appointed to lead a research group and draft a preliminary version of the CPL. ${ }^{35}$ They looked abroad for ways to advance the law and invited foreign experts to share comparative experience. Finally, the CPL drafted by them contained 329 articles, many of which were translated from the German, Italian, and French codes. $^{36}$

We appreciate the scholars' contribution, but 'grand theory' and comparative studies should be carefully construed before guiding our own legal reform. It cannot be assumed whether the 1996 CPL revision would be better if it was not "made in a hurry." However, what seems evident now is the importance of asking what kind of adversary system the stakeholders need. Lawyers were almost completely excluded from the law-making process; they could simply express indirect opinions through the MOJ and a few prominent scholars. ${ }^{37}$ Though about 65 percent of the content of the scholarly-drafted act was finally incorporated into the $1996 \mathrm{CPL}$, some important articles, such as the privilege against selfincrimination and exclusionary rules, remained controversial among the judicial representatives and scholars. ${ }^{38}$ The 1996 CPL was not only a revision made in a hurry, but also a risky compromise between ideals and reality.

Another lesson is that the 1996 CPL reform illustrates the importance of legal experimentalism. Heilmann and Perry have demonstrated an experimentationbased style in China's policy generating process, which is a pragmatic tried-andtested method of handling problems that combines central policy-making with decentralized experimentation. ${ }^{39}$ As an important component of successful legal reforms, experimentalism has been particularly pivotal in facilitating reforms and creating stronger institutions. ${ }^{40}$ However, all the new rules of the 1996 CPL were not tested or modified before extensive implementation, and failed to reflect and solve the key problems in practice. This lesson requires law-making to be evidence-based, showing which legal instruments or ideals work and which do 
not.

Taking the 1996 CPL reform as an example, my aim is to cool down the heated but purely academically-motived suggestion for a Chinese Gideon without enough experimentations or concerted support from the judiciary and lawyers. Because any scholarly endeavor needs to be discussed, one can expect that reform will generate a legal framework sufficiently reflective of and responsive to the needs of the judiciary and lawyers. Though there seems to be a scholarly consensus, my claim here is to provide sober second thoughts before transplanting the American Gideon.

\section{Funding Matters: Insufficient ApPropriations aNd New Challenges}

When looking at the constitutional rights enumerated in the US Bill of Rights, the right to counsel is distinctive in its affirmative nature. ${ }^{41}$ It means that the government cannot ensure the right merely by abstaining from impermissible intrusions, but only by directly channeling resources for that particular purpose. The Gideon holds that the government pay for and provide an attorney for those who cannot afford it and face the loss of their liberty because of imprisonment. ${ }^{42}$ Quality legal representation cannot be offered unless defense system for the indigent is adequately funded. However, the USSC remained silent on the appropriate mechanisms for the funding, and most states and counties refused to provide funding necessary for the counsel and equal justice, despite repeated reports of deficient representation and gross miscarriages of justice. ${ }^{43}$

To make the judiciary in China be more independent of local officials, the CCP and the SPC are exploring a separated budget mechanism for the courts. ${ }^{44}$ Also, the SPC's Fourth Five-Year Plan for People's Courts stresses a centralized and more generous appropriation. The Deputy President of the SPC, Deyong Shen, highlighted that the right to counsel was fundamental human rights in the criminal justice system and urged the courts to respect lawyers and their opinions. $^{45}$

No matter how promising those reforms seem to be, it is still unclear how much the legal aid system could share with China's fast-growing economy, 
or how much the indigent defendants could benefit from the incremental appropriations and government's respect for that affirmative right. Next, I will display a funding picture in recent years, and pose some unexpected challenges resulted from bona fide attempts to expand the legal aid.

\section{A. A Basic Picture of the Appropriation and its Implications}

Four indexes are often considered when assessing China's legal aid system: agency, personnel, cases, and budget. A rough overview shows that, from 2004 to 2014, all of them rose significantly with economic booms (Table 1). But those macro data may not be suitable for the Gideon analysis. For one thing, the personnel sharing the budget are largely administrative officers who are not tackling cases. Therefore, the money used to compensate lawyers accounts for a disproportionately small part compared with administrative fees. For another, China provides legal aid in civil, criminal and administrative cases, so its people should further trace how the budget and compensation are allocated among different cases. I will first make a special chart for the expenditure of litigation, and then calculate how much the counsel may be compensated in one case.

Table 1: Macro Development of China's Legal Aid (2004-14) ${ }^{46}$

\begin{tabular}{cccc}
\hline Index & 2004 & 2014 & Increase \% \\
\hline Agency & 3129 & 3263 & 4.28 \\
Personnel & 11377 & 14533 & 27.74 \\
Caseload & 253665 & 1001047 & 293.63 \\
Budget & $2.81^{*}$ & $17.07^{*}$ & 508.38 \\
\hline
\end{tabular}

* Billion yuan

The first level of the Gideon, the right to counsel, largely relies upon the appropriation for legal aid. Many studies have found that most criminal defendants in China are still without legal representation. For example, in accordance with the statistics collected by Xingliang Chen, a distinguished criminal law professor at Peking University, over 70 percent of all trial of criminal cases in China were without lawyer representation. ${ }^{47}$ This was corroborated by another study in the identical year of 2002, which found that about merely 20 percent of defendants 
charged with theft had legal representation. ${ }^{48}$ Ten years later, McConville noticed the similar problem from his analysis of case files. ${ }^{49}$ Before reaching the effectiveness prong of the Gideon, there is still a long march toward the right to counsel of every defendant.

Figure1: Total Expenditure and Litigation Fees

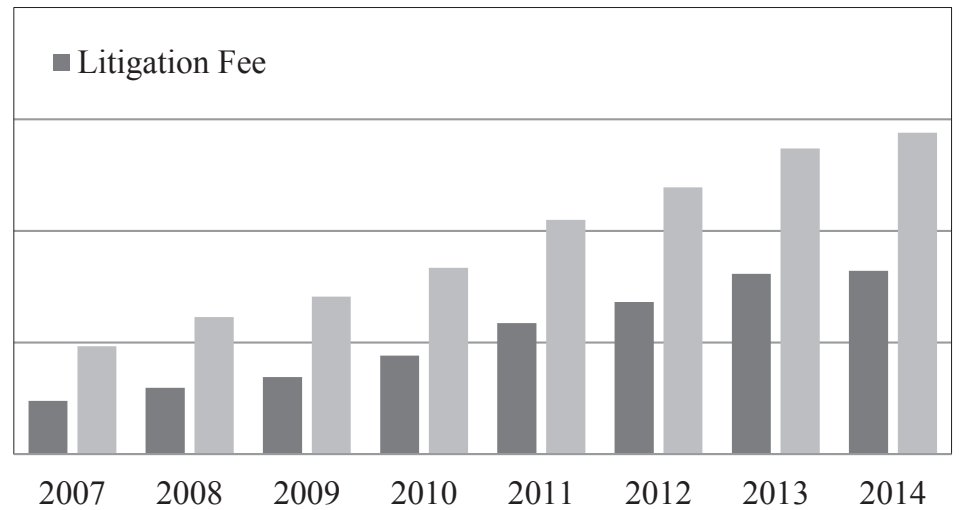

Table 2: Allocation of Litigation Fees (2007-14)

\begin{tabular}{l|ccccc}
\hline 2014 & Compensation & Consulting & Propaganda & Training & Others \\
\hline 2014 & 70.51 & 3.69 & 9.37 & 5.27 & 11.16 \\
2013 & 68.78 & 3.4 & 9.5 & 5.7 & 12.62 \\
2012 & 66.4 & 2.87 & 10.03 & 6.92 & 13.78 \\
2011 & 67.2 & 3.12 & 10.8 & 7.2 & 11.68 \\
2010 & 66.3 & 2.1 & 10.2 & 7.3 & 14.1 \\
2009 & 69.5 & 1.35 & 9.8 & 7.2 & 12.15 \\
2008 & 71.1 & 1.19 & 9.3 & 7.1 & 11.31 \\
2007 & 69.6 & 1.12 & 10 & 7.6 & 11.68 \\
\hline
\end{tabular}

The budget for legal aid is dissected for showing that indigent defendants may not enjoy a pro-rata benefit from the increased investment from 2007 to 2014 (Figure 1). Besides, the litigation fee and daily administrative and personnel fees usually cut into the annual expenditure. For example, they consisted of 9.4 percent and 
31.6 percent of the total expenditure in the 2012-2013 fiscal year, and the rest of 59 percent was the litigation fee for all the cases nationwide. ${ }^{51}$ Furthermore, compensation and its related fees only consist of a majority of the total litigation fee (Table 2), whose proportions fluctuate around 70 percent in recent years. The direct compensation allocated to criminal defense lawyers in each case is even less, because most of the compensation appears in civil cases (Table 3). The compensation for criminal cases, usually less than one third of the total, kept decreasing from 2007 to 2011.

Table 3: Allocation of Compensation (2007-14) ${ }^{52}$

\begin{tabular}{c|ccccc}
\hline Case type & $\begin{array}{c}\text { Civil } \\
*\end{array}$ & $\begin{array}{c}\text { Administrative } \\
*\end{array}$ & $\begin{array}{c}\text { Criminal } \\
*\end{array}$ & $\begin{array}{c}\% \\
* *\end{array}$ & $\begin{array}{c}\text { per case } \\
\text { yuan }\end{array}$ \\
\hline 2014 & 431.07 & 3.85 & 165.29 & 27.54 & 901 \\
2013 & 406.21 & 3.78 & 145.2 & 26.15 & 882 \\
2012 & 351.16 & 4.06 & 97.45 & 21.53 & 879 \\
2011 & 288.91 & 3.46 & 78.79 & 21.23 & 829 \\
2010 & 222.09 & 3.26 & 67.47 & 23.04 & 712 \\
2009 & 165.25 & 2.1 & 65.69 & 28.19 & 634 \\
2008 & 136.93 & 2.23 & 66.35 & 32.38 & 620 \\
2007 & 98.81 & 3.05 & 60.43 & 37.24 & 638 \\
\hline
\end{tabular}

* million yuan ** percentage of criminal compensations

Around 1982, the American Bar Association found that the funding for indigent defense was inadequate, stating: "We must be willing to put our money where our mouth is." ${ }^{, 53}$ In today's China, although the litigation fee shares a majority part of the total budget, the administration and staff are competing for resources. Furthermore, as it is the civil division that enjoys the lion's share of the total compensation, Chinese lawyers should maintain a cautious distance from the media that keep reporting the developments of their legal aid system. The news for criminal legal aid is not cheerful.

This is especially true when it comes to the direct compensation for each criminal case. Admittedly, the number has steadily increased from 2007 to 2014 (Table 3), but is still fewer than RMB 1,000. In view of the disparities 
among different regions, I will select four provinces and their rules, to provide a representative picture of insufficient compensation for each criminal case. The fees charged by privately retained lawyers will be compared. In Beijing, the compensation is calculated based upon the stages of criminal proceedings: the lawyer may get RMB 1,200 at the investigative and prosecuting stages, and then get additional RMB 2,000 if s/he continues to represent the defendant in court. By contrast, one privately retained lawyer can earn more than double that at the same stage (Table 4). ${ }^{54}$

Table 4: Compensations versus Fees (yuan)

\begin{tabular}{|c|c|c|c|c|}
\hline & & investigation & prosecution & trial \\
\hline \multirow[t]{2}{*}{ Beijing } & $\mathrm{L}$ & 1,200 & 1,200 & 2,000 \\
\hline & $\mathrm{P}$ & $2,000-15,000$ & $2,000-15,000$ & $4,000-45,000$ \\
\hline \multirow[t]{3}{*}{ Jiangsu } & $\mathrm{L}$ & \multicolumn{3}{|c|}{$1,800 /$ case, $50 \%-100 \%$ in crease } \\
\hline & $\mathrm{P}_{1}$ & $1,000-8,000$ & $1,500-10,000$ & $2,500-20,000$ \\
\hline & $\mathrm{P}_{2}$ & & $100-2,500 /$ hour & \\
\hline \multirow[t]{2}{*}{ Qinghai } & $\mathrm{L}$ & & $500-700 /$ case & \\
\hline & $\mathrm{P}$ & $300-3,000$ & $500-5,000$ & $600-6,000$ \\
\hline \multirow[t]{2}{*}{ Ningxia } & $\mathrm{L}$ & & $800 /$ case & \\
\hline & $\mathrm{P}$ & $1,000-3,000$ & $1,000-4,000$ & $2,000-6,000$ \\
\hline
\end{tabular}

\section{L: Legal Aid Lawyers P: Privately Retained Lawyers}

In Jiangsu Province, a lawyer representing a defendant throughout a case may get RMB 1,800 , with an increase of 50 to 100 percent in certain circumstances. For privately retained lawyers, two sorts of payments are provided in Jiangsu (Table 4). The first one is akin to Beijing's rule, i.e., pay according to the stage, while the other one is the hourly pay, which can be stipulated in the contract. ${ }^{55}$ However, due to geographic and economic discrepancies, the money sharply reduces to half or one-third in remote areas. For example, the number in Qinghai Province was RMB 500 per case in 2011 and RMB 700 in 2014; ${ }^{56}$ the average number in the newly released regulation of Ningxia Province is about RMB $800 .^{57}$ As shown in Table 4, these amounts are in no way attractive to private-practice lawyers. 
As a direct implication of low compensation, most qualified lawyers would not like to handle legal aid cases. In many jurisdictions of the US, because of the gross underfunding that pervades indigent defense, the poor are often represented by inexperienced lawyers, who view their responsibilities as unwanted burdens. ${ }^{58}$ In China, although legal aid cases are often complicated and the defendants may be sentenced to life imprisonment or death penalty, the level of compensation is insufficient to attract junior lawyers, not to mention those seniors who regularly practice in criminal cases and can make considerable profits as privately retained lawyers.

The experience of Li Chen, a newly-graduated lawyer in Beijing, vividly illustrates what lawyers could do by the compensations. In most cases, suspects are held at a detention center that is usually located in the outskirts of the city. Chen was involved in one legal aid case and went to meet his client twice. Often, as there is no public transportation, he took a taxi back and forth, with a total expense of RMB 460. Each interview took nearly an entire day, but it never freed him from other cases assigned by his boss. In addition to meager compensation, RMB 1,200 , which hardly covers the meals and copying fees, he had to struggle with a busy schedule and was always worn out after work. It was not worthwhile work, both economically and physically, even if he wanted to provide pro bono services. Chen deserves our understanding, since he went to the detention center twice! In other situations, if the victim leaves the city, or one witness lives elsewhere, most lawyers would hesitate to go to meet their clients for a second time.

Poor compensation is not the whole story. What that vision ignores is the day-to-day operation of the 'delivery' system. In the US, problems presented by clients in legal aid offices by and large are dealt with routinely and perfunctorily. In most cases, the lawyers stay in the office and make arrangements for resolving most cases over the phone. Consequently, the representation amounts to no more than a hurried conversation with the accused just before entry of a guilty plea and sentencing. ${ }^{59}$ In many jurisdictions, "meet "em and plead 'em" processing of human beings throughout the courts remain the dominant culture. ${ }^{60}$ This system of criminal procedure is known as 'slaughterhouse justice.'

In China, it has been widely criticized that legal aid lawyers undertake little or no preparatory work in advance of the trial. Article 34 of the CPL requires a defendant, who has certain physical or mental disabilities, or may be sentenced 
to life imprisonment or death penalty can file an application for legal aid. In this case, the court must designate a lawyer to provide legal assistance for him/her. But most lawyers are assigned several days before the trial and appear in the court because they are asked just to satisfy the requirement. Their presence alone is deemed to meet this requirement. ${ }^{61}$ Without adequate pre-trail investigation and other preparatory work by the lawyers, the trial is merely a formality rather than the center as required by the TCR.

It is interesting to find that not all lawyers are reluctant to handle legal aid cases, because they can process cases in a manner akin to the "meet "em and plead 'em" strategy. In practice, there are many 'full-time' legal aid lawyers, who come to the court on the day the cases are heard. The key point of making money is the package-processing strategy, that is, by coordinating with the court and scheduling several cases within one morning or afternoon, which can make them represent many clients easily. They have no disagreement with the charge in the bill of prosecution, and their pleas of mitigation tend to be stereotypical, instead of being defendant-specific. ${ }^{62}$ What they care about is the compensation, rather than the undifferentiated faces of their clients. Such legal aid reduces the Gideon into ornaments, and the right to counsel is being alienated by a tradeoff between conviction and money.

Another ramification of the scarce resource is to preclude the investment in training young lawyers, who are often appointed in legal aid cases. In the US, the practice of criminal law necessitates continuous and comprehensive training for all indigent defense service providers. ${ }^{63}$ However, untrained and unskilled lawyers are often appointed to provide legal service. Thus, a consensus that the complexity of indigent defense practice and the ever-changing nature of legal rules make ongoing training a necessity rather than a luxury has been reached. ${ }^{64}$

Though China's Lawyer Law requires all the lawyers to undertake legal aid work, it neither specifies how much work one lawyer should do, nor regulates whether the lawyer would be disciplined if s/he does not handle any legal aid case Indeed, many lawyers who practice criminal law in their early careers switch to civil and commercial cases after they have established a professional reputation and reached a certain income level. ${ }^{65}$ Many young lawyers began to handle legal aid cases immediately after joining in the firm, and could do the case independently right after getting the bar license. However, what young lawyers 
need are not only a law degree or license, but also formal training in providing representation. Lack of financial support for systematical and routine training prevents them from accumulating knowledge, experience and trial skills.

\section{B. New Challenges after the 2012 CPL and the 18th National People's Congress}

The 2012 CPL rebuilt the legal aid system in two aspects. Firstly, legal aid became available at the investigative and prosecuting stages. Secondly, the scope of legal aid was extended in two ways: 1) it required counsels to be provided when a criminal suspect or defendant is a mental patient who has not completely lost the ability to recognize or control his/her behavior; and 2) it expanded the category of defendants eligible for representation from "the defendant[s] who may be sentenced to death" to those "who may be sentenced to life imprisonment or death penalty." ${ }^{, 66}$ The two expansions were further strengthened by subsequent policies that released after the CCP 18th National People's Congress, which underlined the social fairness and equal justice.

In October 2014, the CCP central committee promulgated "Some Major Questions in Comprehensively Promoting Governing the Country According to the Law" (hereinafter the Decision). ${ }^{67}$ That was the first time the CCP's central committee addressed the legal topic, and the Decision is perhaps indicative of the most far-reaching reform initiative since $1978 .^{68}$ As a supportive mechanism of constructing the rule of law, the Decision requires the government to continuously improve the legal aid system, broaden the scope of aid, and guarantee that the popular masses obtain timely and effective legal assistance when they encounter

problems. ${ }^{69}$ Subsequently, MOJ defined legal aid as a 'livelihood project' in $2015^{70}$

However, the Gideon's mandate is a welfare program, which is politically unpopular and fares poorly when compared with other government programs that can promote economic growth in a short term. ${ }^{71}$ To achieve better and equal protection is not as easy as adopting a political declaration. We live in a world of scarcity, where the underfunded legal aid system is being compounded by ambitious promises without corresponding appropriations.

The year of 2013 is critical, because the 2012 CPL expanded legal aid and new rules took effect in 2013. From 2012 to 2013, the number $(N)$ of criminal legal aid cases nationwide increased by 66.2 percent, which significantly surpasses the 
growth rate in previous years. Meanwhile, the total compensation allocated to criminal cases $(S)$ increased by only 49 percent, indicating that the compensation failed to keep pace with the explosive caseload. Moreover, one should be surprised to find that the average compensation for criminal cases $(A)$ remained roughly stable, from RMB 879 to $882 .^{72}$ All these trigger further analysis of the funding and the caseload in the field of criminal legal aid.

$$
A(\text { stable })=\frac{S \uparrow}{N \uparrow}
$$

Firstly, the unbalanced growth rate between $S$ and $N$ means the incremental investment cannot change the status quo of underfunded criminal legal aid. If hoping to increase $A$ and improve the lawyer's performance accordingly, more money should be invested in $S$. Let's take Shenzhen city as an example. Shenzhen is a special economic zone located on the coast of South China. Macrolevel analysis shows that though the appropriation sharply increased by nearly 150 percent from 2012 to 2013, the increasing ratio of litigation fees fell behind the explosive caseload after 2012, which generated a deficit of RMB 6 million in 2013. Worse still, Shenzhen only hired seven full-time lawyers to review about 20,000 applications, so that the process was seriously delayed by additional affairs. $^{73}$

Secondly, under current conditions, such equation indicates at least in some criminal cases, the compensations decreased, or the suspect and defendant did not get the legal aid at all, since $N$ must be cut off in order to achieve the balance of equation. Another alternative explanation is that many cases remained unsolved in the end of the fiscal year of 2013, and lawyers were not compensated before completing works. This explanation gains support from the fact that only 72.1 percent of criminal cases were solved in 2013, while the number in 2012 was 83 percent. $^{74}$ One of the reasons for the decline is the understaffed legal aid system. If no more lawyers are attracted or employed, there would be more cases unsolved in the next years.

Thirdly, the growth rates of caseloads and budgets were disparate in different regions of China. In 2013, the caseload rose over 100 percent in seven provinces, including Jiangxi and Jiangsu. Consequently, Jiangxi Province forced the legal 
aid center either to raise the threshold or expedite processing minor cases. ${ }^{75}$ Meanwhile, in Shanxi and Jilin provinces, the growth rate was less than 20 percent, and, most surprisingly, it declined in three remote provinces. ${ }^{76}$ In order to tackle the caseload crisis, some provinces with good economic situations started to provide specific funds. For example, Jiangsu appropriated RMB 15 million to alleviate financial burdens of local bureaus of MOJ. ${ }^{77}$ Nonetheless, most provinces continued to rely upon MOJ's appropriations for maintaining the daily operation of legal aid centers. It is fair to say that they are in the troubling position, where the status quo spending on criminal legal aid would not even maintain a status quo of capabilities, let alone fulfill the Gideon's promise.

Fourthly, as a critical reform mandated in the Decision, the TCR highlighted the importance of criminal defense lawyers and the legal aid system. Accordingly, Deyong Shen and Guangzhong Chen, who were pivotal in the 2012 CPL reform, both suggested learning Zhejiang's reform that had been experimented in piloted points, and expanding the criminal legal aid in cases, where a suspect or defendant shall be sentenced to fixed-term imprisonment of three years or a lighter punishment. ${ }^{78}$ However, they did not take a full account of Zhejiang's fairly good economic situation, which ensured adequate annual budget and specific funds for less developed areas. In view of the uneven economic developments in China, I am uncertain about other provinces' willingness and capacities to afford such a luxury promise.

The status quo of appropriation, compensation and their tensions under new challenges displays a picture of our underfunded legal aid system. Statistics and examples might not represent the climate in individual provinces and cities, but, at least, they have shown that tensions between rules and reality, between available funding and shortage of staff, and between ambitious promises and staggering practice, are worsening in the day-to-day delivery system. A bigger cake cannot meet the even bigger needs.

When the budget cannot keep pace with the growing caseload, there is a substantial risk that suspects and defendants will not receive adequate legal representation and that wrongful convictions will occur. ${ }^{79}$ Therefore, in today's China, any romantic sound of the Gideon's trumpet needs a second thought before a nationwide adventure. 


\section{Institutional Obstacles to the Chinese Gideon}

Funding is only one factor when evaluating the Gideon's two dimensions. This part first surveys the current situation of China's legal aid system, and then diagnoses structural impediments to the criminal defense in a broader manner. Though it is desirable for more members of the legal profession to shoulder their ethical obligations to provide legal assistance, the criminal defense work often requires more institutional arrangements than that individual lawyers are able to offer.

\section{A. Effectiveness of China's Legal Aid}

The quality of representation is a common topic in the US and China. Gary Bellow once expressed his concerns that growing caseloads would erode the quality of service and inhibit the potential of strategic lawyering to benefit the poor. ${ }^{80}$ In this case, a quality assurance mechanism was introduced in the past decade including substantive protocols and practice standards, outcome measures and assessments, and the review of casework performance. ${ }^{81}$ All these are contained in the basic structure of Strickland that creates a 'performance-prejudice' test for determining ineffective-assistance-of-counsel ("IAC") claims.

Despite of the declaration that "quality is the lifeline of legal aid," MOJ provides few practicable methods for controlling and evaluating the quality. Liebman found that China is focusing on expanding the number of legal aid programs and institutions at the expense of ensuring legal aid work which is adequately performed. ${ }^{82}$ His argument can gain support from other surveys. For example, Yansheng Zhang made a follow-up study in 100 legal cases and ranked the feedback into three groups: pretty bad, bad, and good groups. In those 27 percent of 'pretty bad' cases, some lawyers did not interview their clients, while others just wrote two-to-four-page opinions. Only 10 cases were accredited to be 'good,' but there was no one case, in which the lawyer investigated outside the office. $^{83}$ Another empirical study from Sichuan Province also showed that from lawyers' standpoint, legal aid at the investigating stage had no (80\%) or little effect $(20 \%){ }^{84}$

Many Chinese scholars, using Strickland to criticize the effectiveness of legal aid, have proposed Strickland's "double-prong standards," 
guidelines, ${ }^{86}$ or supported an enforcement mechanism of effective representation for improvement. ${ }^{87}$ However, their suggestions, as well as MOJ's pronouncements about the importance of counsel, have not realized quality criminal defense. In this case, how can we expect the underfunded and untested Gideon to improve the overall quality of criminal defense? If most indigent defendants have counsels, or if the quality of current legal aid ranks the 'good' in the majority of cases, I would zealously embrace a Chinese Gideon in all criminal cases. However, this is not the case.

\section{B. The Linear Structure and Institutional Obstacles}

Both the American and Chinese legal aid systems are plagued by institutional impediments that go beyond lack of resources. In the US, the Gideon is not welcomed among prosecutors and judges, because the criminal defense lawyer could frustrate the government's efforts to convict defendants. ${ }^{88}$ Many prosecutors improperly seek waivers of counsel from unrepresented indigent defendants. ${ }^{89}$ Judges either tolerate or openly encourage inadequate representation, since it allows them to process cases efficiently. Worse still, some may threaten defendants with the 'trial penalty.' In other words, a request for lawyers would delay their case. Moreover, refusing a plea offer would result in a harsher sentence in the future. ${ }^{90}$

A typical Chinese criminal trial seems more akin to a guilty plea allocution than a trial that tests disputed facts or contested explanations of evidence. ${ }^{91}$ At the pre-trial stage, the police and the prosecutor have informed the suspect of a long-established policy of "Leniency to Confessors, Severity to Resisters," which encourages cooperation and the waiver of the right to counsel. When cases go to trial, prosecutors and judges may pressure defendants to settle cases absent a lawyer, or offer lighter sentences if defendants do not hire a lawyer. ${ }^{92}$ Such 'trial penalty' results in an abnormal conviction rate in China.

The extremely high conviction rate reflects the constitutional relationship between China's police, procuracy and the court. Article 135 of the PRC Constitution requires: "They shall coordinate their efforts and check each other to ensure the correct and effective enforcement of the law." This cooperative nature determines the structure of criminal procedures in profound ways. In the adversary trials, the triangular structure - a judge sitting at the vertex to hear disputes between 
parties - is designed under the theory of checks and balances. This assumes the supremacy of court in a constitutional context and ensures equal arms between parties. However, Article 135 establishes a linear structure at the horizontal level, which stresses collaboration rather than checks and balances, and prefers "correct and effective enforcement of the law" to other competing values.

Unlike the "due process model," which looks like an obstacle course, the linear structure is an assembly line that is closer to the "crime control model." ${ }^{.93}$ Each of the criminal procedures is not designed to present impediments for carrying the accused any further along in the process. Instead, they work in streamline fashion, in which the police, procuracy and the court share the same goal of solving cases and punishing criminals correctly and expeditiously. ${ }^{94}$ The linear structure possesses two main features.

Firstly, the police, procuracy and the court are completely separated and independent from one another, each of which is an ultimate authority at the investigative, prosecuting and trial stages. The police have complete control over the investigation of a case. Without substantive restrictions, they can both $e x$ officio deprive the freedom and property of suspects, and exert direct or indirect influence for obtaining confessions and then proving that the case reaches an extremely certain level before prosecution. In addition, as another employee in the assembly line, prosecutors will review the investigative work, and advance or shore up the case prepared by the police. If there are problems or weaknesses in the evidence, prosecutors will either ask the police to conduct supplementary investigation, or take steps by themselves to make good any shortfall. ${ }^{95}$

Prosecutors will advance the case to trial when they determine that "the fact is clear, and the evidence is hard and sufficient" - which is also the standard of proof of final convictions. This mechanism of two identical standards foretells the guilty judgments, because it is easier for the court to doubly check the fact-finding that has been verified by the prosecutor. Furthermore, China's prosecutors can use discretion to 'filter out' the cases that are likely to be acquittals. ${ }^{96}$ In this way, judges can only see what prosecutors want them to see. Showing little humaneness or mercy to defendants, this linear structure is conducive to manufacturing a conviction by any means.

Secondly, lawyers are marginalized in the linear structure. The 1980 Regulations on Lawyers defined the lawyers as "state legal workers" who 
should protect socialism and promote economic growth. ${ }^{97}$ Their status, however, was inferior to the police, prosecutors and judges in the legal system. This asymmetrical relationship was aggravated when the 1996 Lawyers Law redefined them as "social legal workers." reduces its political status and influence on the decision-making process. ${ }^{99}$

Lawyers' voices were largely ignored in the process of revising the 1996 CPL. In practice, lawyers may assert that they can add value by arguing for leniency and facilitating negotiations with prosecutors and judges, but their role is still unimportant in affecting outcomes. ${ }^{100}$ Normative and empirical studies have shown that the entire criminal process is under tough control of the 'iron triangle' that includes the police, procuracy and the court, while excluding the lawyer. Moreover, the 'iron triangle' fails to value the work of Chinese criminal defense lawyers, and even assigns blames to lawyers for being incompetent and irresponsible. $^{101}$

The criminal justice machine is designed to process criminals. In this regard, any countervailing force will be ruthlessly marginalized or eliminated. The conviction-based linear structure can be further analyzed in another empirical study conducted in Beijing. Yongzhong $\mathrm{Gu}$ and his team surveyed 300 criminal cases. It was shown that lawyers provided legal assistance for 213 defendants, when 97 percent of them confessed and accepted the charges before trial. For the rest six defendants, their lawyers performed as dedicated as possible with additional compensations from that research project. However, the courts convicted all the defendants eventually, while only changing the nature of three charged crimes. In 171 cases, the courts accepted the defense opinions, all of which were mitigation, while all the pleas for mitigation for un-confessed defendants were rejected. ${ }^{102}$

This study provides illuminating answers to the question whether lawyers do matter in the linear structure. Gu's project relies on a perfect environment, where lawyers need not to worry about the schedule, money and resistance from the 'iron triangle.' Defendants can meet at least one lawyer at least once; talk with them without interruption or monitoring; ask them to collect additional evidence; and most markedly, refuse to confess in six cases. Moreover, the 'iron triangle' kept friendly to criminal defense lawyers all the time. Needless to say, the bottom line was secured: everything could be negotiated except the conviction, which means that criminal defense is rarely effective when a lawyer contests guilty, and winning 
a non-guilty judgment is nearly impossible. ${ }^{103}$

It is unfair to say that lawyers are of little importance in the linear structure. However, I am still unconfident of the right to counsel to some extent in view of the following realities: (1) most indigent defendants cannot afford a lawyer; (2) most lawyers often neglect obligations due to limited resources and overloaded work; and (3) some officials are used to be obstructive and inefficient. The effective assistance of counsels would hardly make differences as long as the criminal justice machine remains to be expected to control crimes and maintain social stability, and the linear structure continues to push the 'iron triangle' to produce convictions. Even the most effective assistance of counsels appears to be able to change the linear structure, not to mention that the reasonableness-based Gideon never mandates more competence, diligence and experience than a normal level.

\section{Difficult and Risky LAWYering}

Anyone unfamiliar with the Chinese criminal justice system would be surprised by the daunting difficulties that criminal defense lawyers face in their everyday practice. ${ }^{104}$ They are not only marginalized, but also sometimes prosecuted or persecuted by the 'iron triangle.'

The failures of individual lawyers are often the product of the linear structure that prevents well-intentioned lawyers from meeting their clients, accessing case materials, and collecting evidence. These 'Three difficulties' and Article 306 of Criminal Law, known as a 'big stick' hanging over lawyers' heads, compromise the major problems encountered in criminal defense practice. Article 306 regulates the criminal punishment of lawyers who falsify or suppress evidence or instruct their clients in falsifying or suppressing evidence. ${ }^{105}$ It often targets lawyers in a retaliatory fashion for trying to challenge the prosecutor's evidence, because the investigating and prosecuting authorities are unwilling to see the result of their own work challenged. ${ }^{106}$ Particularly, when defendants change confessions or decline to confess again in court, there will be a high possibility of triggering the bomb of Article 306. As the 108th lawyer who was charged under Article 306, Zhuang Li was convicted and sentenced only in eighteen days. This 
hotly-debated case not only aggravates difficulties in representation of criminals, but also has a chilling effect on the entire legal profession. ${ }^{107}$

The 2012 CPL was amended in response to persistent criticisms of 'Three difficulties" and "Big stick 306," which has somewhat ameliorated those problems. However, the difficulty of meeting clients in corruption cases still exists. Article 37 of the $2012 \mathrm{CPL}$ requires the detention center to arrange a meeting no later than forty-eight hours after a lawyer files a request. If his/her client is suspected of compromising extraordinarily significant bribery, however, the meeting shall be subject to the permission of the criminal investigation authority. Unfortunately, the 2012 CPL fails to specify what an "extraordinarily significant bribery" case is, while the procuracy enjoys wide discretion in individual cases. Many lawyers have reported that their requests for meeting clients are all denied on the ground of "extraordinarily significant bribery.", 108

In practice, lawyers and bars have aroused attention concerning "three new difficulties" at the trial stage, being difficult to: (1) ask prosecutors questions; (2) confront witnesses against their clients; and (3) present defense opinions in court. Firstly, the 2012 CPL encouraged lawyers to play an active role in preventing miscarriages of justice, but they are often stopped by the residing judge when asking questions in court. For example, one empirical study showed that 90.8 percent of interviewees suffered had restrictions of the time, scope, and content of asking questions. ${ }^{109}$

Secondly, in most cases, the prosecutor's witnesses remain absent in court. Even in cases where witnesses do appear, lawyers are neither allowed to confront adverse witnesses against their clients, nor invite their own witnesses to provide testimonies. Article 187 of the 2012 CPL stipulates that when a witness statement has a material effect on the conviction and sentencing, the witness shall testify before the court if the court deems it necessary. However, from the abovementioned empirical study, it was found that nearly 92 percent of the prosecutor's witnesses never appear in court. When lawyers attempted to confront them and requested the court to call them to testify in court, nearly half of requests were denied because the court preferred reading written testimonies after the trial. ${ }^{110}$

Thirdly, the court may place indirect obstructions on lawyers' speeches in court. It has been a common phenomenon that the lawyer's speeches are abruptly interrupted or unreasonably restricted. For example, some lawyers are permitted 
to deliver opinions within limited time (usually fifteen or twenty minutes), but their speeches would be interrupted when the court deems they are irrelevant or iterative. Most surprisingly, the court often encourages lawyers to submit written opinions after the trial. If lawyers show disrespect for the court's advice, their pleas for mitigation would be disregarded.

Finally, with respect to "Big stick 306," there is no exact number of lawyers who have been charged under Article 306 since 2012. However, it has been noticed that human right lawyers and other activists now face harsher compulsory measures at the pre-trial stage when they represent suspects in 'national security' crimes. ${ }^{111}$ Besides, most criminal defense lawyers remain focusing on sentencing mitigation, because, as for a survival strategy, it is unwise to challenge and piss off the 'iron triangle.'

Therefore, the criminal defense is the most demanding and dangerous work in China. Lawyers have to not only persuade the 'iron triangle,' but also work under the risk of being prosecuted or persecuted. On this account, how could we be overcritical of lawyers' self-preservation strategies: occasional interviews, infrequent investigations, and abstinence of contacting the prosecutor's witnesses? A logical inference from the weak lawyering is the even weaker defendant. There is another caveat here. Even if there were sufficient funds for legal aid, could the defendant appoint an effective lawyer who dares to work in defiance of "Big stick 306," to persuade witnesses to change testimonies, and to repeatedly challenge the conviction through appeals?

\section{INADEQUATE OR INACCESSIBLE REMEDIES FOR THE GIDEON Claims}

The primary mechanism for enforcing the Gideon's promise is an individual criminal defendant's ability to argue that s/he received ineffective assistance of counsels. ${ }^{112}$ Strickland and subsequent cases have clearly indicated that the judicial scrutiny of counsels' performance must be highly deferential ${ }^{113}$ and surmounting Strickland's high bar is never an easy task. ${ }^{114}$ In practice, appellate courts rarely support the IAC claims. ${ }^{115}$

The US provides a mirror for the enforceability and practicability of the Chinese 
Gideon. Can the IAC claims then be heard in the Chinese court? In the trial court, as the prejudicial impact from counsels' effective performance is not ready to observe, the appellate court is the primary forum for the IAC claims. Article 227 of the 2012 CPL enumerates five situations, where cases should be remanded for the retrial in the second-instance court:

(1) The provisions of the CPL regarding open trial are violated;

(2) The disqualification provisions are violated;

(3) A party involved is deprived of statutory procedural rights or such rights of a party concerned are restricted, which may affect a fair trial;

(4) The composition of a trial organization is illegal;

(5) Statutory procedures are otherwise violated, which may affect a fair trial.

Sections (3) and (5) are the most promising statutory grounds for the IAC claims. However, based upon what I am informed of in ten-year's studies of criminal justice, there is no one case remanded for the retrial under section (3) or section (5). In a different word, when those enumerated rights have yet been legal grounds for a retrial, how could we expect the court to support a pioneering idea of overturning the conviction due to incompetent counsels?

In addition, the IAC claims are unreviewable in the newly-established circuit courts in China. They are adjudicatory organs designated by the SPC, for the purpose of reducing local officials' interference in the judiciary. ${ }^{116}$ In the beginning, with American habeas corpus in mind, I was guessing whether circuit courts could hear the IAC claims. Shortly, pursuant to the SPC's judicial interpretations released in January 2015, they lack jurisdictions over ordinary criminal cases, except the criminal petitions. All possible ways of hearing the IAC claims in the current system have hitherto been exhausted. If rights require remedies, a corollary of this process is neither less true, nor remedies and rights. Besides, this should be kept in mind before transplanting the American Gideon for addressing China's problems. 


\section{Conclusion}

This paper attempts to re-envision the Gideon's promise and failure in a comparative framework between the US and China. A closer examination of China's criminal justice system and legal profession illustrates the importance of keeping a sober vision of the Gideon, which is drawn distinctly from American experience and might be not particularly meaningful in today's China. In Chinese context, when legal aid is underfunded and understaffed, institutional obstacles are difficult to overcome, and legal remedies are inaccessible. However, I am not to deny the Gideon and its supportive mechanisms, but to argue that the forces that are the most essential for the support of the Gideon can only come from China itself.

Firstly, American lessons show that an unfunded mandate to provide the attorney for the poor without any mechanism for ensuring adequate resources is unlikely to succeed in providing competent counsels. ${ }^{117}$ In China, though there are signs that the $\mathrm{CCP}$ and MOJ are discharging their duty to appropriate more funds and attract competent lawyers in the legal aid, it remains unclear whether the gap between demand and supply would start to narrow in the coming years. It is also unlikely that the 'iron triangle' and lawyers, after years of neglect, would respond effectively to this worsening situation merely due to scholars' advocacy. Therefore, the CCP and MOJ must provide adequate resources and enforcement mechanisms while making luxury promises.

Secondly, Chinese scholars should keep both academically vigilant regarding the relevance of successful experiences of the US, and doubly vigilant when introducing the Western experience for tackling their problems. The broken promise of the American Gideon has hitherto attracted scant attention in China. If hoping to use the American Gideon to improve legal representation in China, its pros and cons must be first scrutinized so as to avoid the plight of insufficient resources, overwhelming caseloads, and inadequate remedies.

Thirdly, institutional challenges, both in the US and China, are so widespread and complex that there is no silver bullet to overcome them. China could steadily increase the budget of legal aid in a manner even more generously than the US and incorporate the Gideon with the stroke of a pen. As a prerequisite, however, the constitutional linear structure must be reshaped. Further improvement of our 
criminal justice system requires a thorough mapping of interactions between the 'iron triangle' and lawyers.

Finally, in a broader sense, the tension between universalism and relativism should be seriously treated when China attempts to advance the criminal defense and the entire legal reform. The Gideon is certainly a necessity to ensure a fair trial in individual cases. What is needed next is to localize the approach with a detailed understanding of newly-pressing interests and the current situation, and then to process feasible solutions that have been tested by experience in domestic context, rather than mimic Western successes without academic vigilance. ${ }^{118}$ In this case, less sweeping and more flexible models are required, so that a Chinese scheme can fulfill the Gideon's promise.

\section{REFERENCES}

1. R. Pound, Comparative Law and History as Bases for Chinese Law, 61 HARv. L. Rev. 74962 (1948). [Emphasis added]

2. Id. at 751 .

3. Powell v. Alabama, 287 U.S. 45 (1932).

4. Gideon v. Wainwright, 372 U.S. 335 (1963).

5. S. Bright \& S. Sanneh, Fifty Years of Defiance and Resistance after Gideon v. Wainwright, 122 Yale L. J. 2150-75 (2013).

6. B. Liebman, Lawyers, Legal Aid, and Legitimacy in China, in RAIsing the Bar: The Emerging Legal Profession in East Asia 311-55 (W. Alford eds., 2007).

7. Turner v. Rogers, 564 U.S. 431 (2011).

8. Article 41 of the 1978 Constitution and Article 25 of 1979 CPL both recognized that "the defendant has the right to counsel."

9. See, e.g., Yinghui Song, Basic Theories of Criminal Procedure [刑事诉公原理] 118 (Law Press, 2007); Chongyi Fan \& Xiaohua Ye, On China's Criminal Defense Reform from the Principle of Effective Representation [从有效辩护原则看我国刑事辩护改革], 10 CHINESE LAW. [中国律师] 60-62 (2007).

10. W. Alford, On the Limits of "Grand Theory” in Comparative Law, 61 WASH. L. REv. $945-$ 56 (1986).

11. Gideon v. Wainwright, 372 U.S. 344 (1963). (Lawyers in criminal courts are necessities, not luxuries).

12. C. Steiker, Gideon's Problematic Promise, 143 Daedalus 51-61 (2014). 
13. Gideon v. Wainwright, 372 U.S. 344 (1963).

14. Strickland v. Washington, 466 U.S. 686 (1984).

15. C. Albert Hy, An Introduction To The Legal System Of The People’s Republic of CHINA 4 (4th ed. 2011).

16. Luye Mou, Breakthroughs and Limitations of Judicial Reform, 1 Peking U. L. J. 459-500 (2013), available at https://www.tandfonline.com/doi/abs/10.1080/20517483.2014.114244 80 (last visited on Jan. 29, 2019).

17. P. Butler, Poor People Lose: Gideon and the Critique of Rights, 122 Yale L. J. 2176-204 (2013).

18. Xiao Yang, Establishing the Legal Aid System with Chinese Characteristics [建立有中国特 色的法律援助制度], People's Daily [人民日报], May 4, 1996.

19. SPC and MOJ, Notice on Legal Aid in Criminal Cases [关于开展法律援助工作的通知] (June 3, 1996); Regulations on Legal Aid [法律援助条例] (promulgated by the State Council, Jul. 16, 2003, effectively Sept. 1, 2003).

20. Legal Affairs Committee of National People's Congress Standing Committee [全国人大 常委会法制工作委员会], Article Explanations, Legislative Reasons, and Related Rules of Decision on Revising the Criminal Procedure Law of People's Republic of China [关于修 改中华人民共和国刑事诉讼法的决定：条文说明、立法理由及相关规定] 15 (Peking University Press, 2012).

21. Yan Zhang, Free Legal Aid Program in China Sees Expansion, China Daily, July 22, 2015, available at $\mathrm{http}: / /$ usa.chinadaily.com.cn/epaper/2015-07/22/content_21379168.htm (last visited on Jan. 15, 2019).

22. Ake v. Oklahoma, 470 U.S. 77 (1985).

23. P. Mann, Ethical Obligations of Indigent Defense Attorneys to their Clients, 75 Mo. L. REv. 715-49 (2010).

24. Strickland v. Washington, 466 U.S. 687 (1984).

25. Liebman, supra note 6, at 339.

26. M. McConville, Criminal Justice in China: An Empirical Enquiry 190 (2011).

27. Hong Lu \& T. Miethe, Legal Representation and Criminal Processing in China, 42 BRIT. J. Criminology 267-80 (2002).

28. Song, supra note 9, at 118.

29. Ruihua Chen, Effective Representation in Criminal Cases [刑事辩护中的有效辩护问题], 5 Suzhou U. J. [苏州大学学报] 94-105 (2014).

30. Ji Xiangde, Universal Values and Effective Representation [刑事辩护准入制度与有效辩护、普 遍辩护], 4 Tsinghua L. REv. [清华法学] 116-31 (2012).

31. Deyong Shen, China's Trial Centralization Reform [论以审判为中心的诉讼制度改革], 3 China Legal SCI. [中国法学] 5-19 (2015).

32. See Lawyers Committee for Human Rights, Lawyers in China: Obstacles to INDEPENDENCE AND the DeFENSE of Rights 95-6 (1998). 
33. Lu \& Miethe, supra note 27, at 277.

34. Id.

35. Sida Liu \& T. Halliday, Recursivity in Legal Change: Lawyers and Reforms of China's Criminal Procedure Law, 34 L. \& Soc. InquiRy 911-50 (2009).

36. Id. at 919 .

37. Id. at 927.

38. Id. at 928 .

39. S. Heilmann \& E. Perry, Embracing Uncertainty: Guerrilla Policy Style and Adaptive Governance in China, in Mao's Invisible Hand 1-29 (Heilmann \& Perry eds., 2011).

40. B. Liebman, Assessing China's Legal Reforms, 23 Colum. J. Asian L. 17-33 (2009).

41. Steiker, supra note 12, at 53.

42. E. Chemerinsky, Lessons from Gideon, 122 YALE L. J. 2676-93 (2013).

43. Bright \& Sanneh, supra note 5, at 2153.

44. D. Clarke, China's Legal System and the Fourth Plenum, 20 Asian PoL'y 10-6 (2015).

45. Shen, supra note 31, at 15-6.

46. MOJ, Yearbook of Legal Aid in China [中国法律援助年鉴] 98 (Law Press, 2005); Yearbook of Legal Aid in China 206-7 (2014).

47. Liu \& Halliday, supra note 35, at 937.

48. Lu \& Miethe, supra note 27, at 276.

49. McConville, supra note 26, at 293.

50. MOJ, YeArbooK of Legal Aid in China 154 (2007), 160 (2008), 183 (2009), 191 (2010), 224 (2011), 212 (2012), 200 (2013) \& 206 (2014).

51. MOJ, Yearbook of Legal Aid in China 200-1 (2013).

52. Id.

53. S. Bright, Counsel for the Poor: The Death Sentence Not for the Worst Crime but for the Worst Lawyer, 103 Yale L. J. 1835-83 (1994).

54. Beijing People's Government (Bureaus of Finance and Justice), Regulation on Legal Aid Compensations in Beijing [北京市法律援助补贴办法] (Nov. 22, 2011).

55. Jiangsu Province Government (Bureaus of Finance and Justice), Notice on Regulation on Compensation for Legal Aid [关于规范法律援助经费使用管理的通知] (Nov. 3, 2008).

56. Qinghai Province Government (Bureaus of Finance and Justice), Qinghai Province Notice on Increase the Compensations for Legal Aid [青海省调整法律援助经费的通知] (June 18, 2007).

57. Ningxia Province Government (Bureau of Justice), Ningxia Hui Autonomous Region Regulations on Quality Evaluation and Compensations for Legal Aid [宁夏回族自治区法律 援助质量评估及办案补贴管理办法] (Jan. 1, 2009).

58. Bright, supra note 53, at 1849-50.

59. ABA Standing Committee on Legal Aid and Indigent Defendants, Gideon's Broken Promise, The American Bar Association Website (Dec. 2004), available at https://www. 
americanbar.org/content/dam/aba/administrative/legal_aid_indigent_defendants/ls_sclaid_ def_bp_execsummary.authcheckdam.pdf (last visited on Jan. 15, 2019).

60. Bright \& Sanneh, supra note 5, at 2152.

61. McConville, supra note 26, at 304.

62. Id. at 315 .

63. Gideon's Broken Promise, supra note 59, at 11.

64. Steiker, supra note 12, at 55.

65. Sida Liu \& T. Halliday, Political Liberalism and Political Embeddedness: Understanding Politics in the Work of Chinese Criminal Defense Lawyers, 45 L. \& Soc'y Rev. 831-66 (2011).

66. 2012 CPL art. 34, available at http://www.npc.gov.cn/npc/lfzt/rlyw/2018-04/24/ content_2053277.htm (last visited on Jan. 15, 2019).

67. CCP Central Committee, CCP Central Committee Decision concerning Some Major Questions in Comprehensively Moving Governing the Country According to the Law [中共中央关于全面推进依法治国若干重大问题的决定] (Oct. 20, 2014). English version is available at https://chinacopyrightandmedia.wordpress.com/2014/10/28/ccp-centralcommittee-decision-concerning-some-major-questions-in-comprehensively-movinggoverning-the-country-according-to-the-law-forward (last visited on Jan. 15, 2019).

68. K. Brødsgaard, Assessing the Fourth Plenum of the Chinese Communist Party, 20 Asian PoL'y 30-7 (2015).

69. Decision, §§ 4 (5) \& 5 (3).

70. Dacheng Zhao, Deputy Minister of Justice Mr. Zhao Dacheng: To Improve the Legal Aid System [司法部副部长赵大程: 完善法律援助制度], PeOpLE's DAILY [人民日报], Jan. 9, 2014.

71. Steiker, supra note 12 , at 54.

72. MOJ, supra note 51.

73. Bixue Wang \& Enhui Cao, Legal Aid: Free Meal of Guaranteed Quality [法律援助: 质量有 保障的“免费餐”], PEOPLE’s DAILy [人民日报], Mar. 26, 2014.

74. MOJ, supra note 51, at 200.

75. Id. at 202.

76. Id.

77. Id. at 205.

78. Shen, supra note 31, at 14. See also Guangzhong Chen, A Tentative Analysis on Trial Centralized Reform [审判中心与相关诉讼制度初探], 2 TRIBUne OF Political SCI. \& L. [政法 论坛] 120-8 (2015).

79. National Right to Counsel Committee, Justice Denied: America's Continuing Neglect of Our Constitutional Right to Counsel (hereinafter Justice Denied), The Constitution Project and the National Legal Aid \& Defender Association Website (Apr. 2009), available at http://constitutionproject.org/wp-content/uploads/2012/10/139.pdf (last visited on Jan. 15, 2019). 
80. J. Charn, Time for a System Wide Quality Agenda, Mgmt. Information Exchange J. 1-9 (2004).

81. Id. at 4-7.

82. Liebman, supra note 6, at 339.

83. Yansheng Zhang, Status Quo and Improvements of China's Legal Aid [我国刑事法律援助的 现状与完善], in Research on Criminal Legal Aid of China’s Practice and International VISIONS [刑事法律援助的中国实践与国际视野] (hereinafter RESEARCH ON CRIMINAL LEGAL AID) 216-23 (Yongzhong Gu ed., 2013).

84. Sichuan Province Legal Aid Center, Report on Criminal Legal Aid at the Pretrial Stage [审 前阶段的法律援助报告], in Reform And Development of China's Legal Aid System [法律援 助制度改革与完善] 63-68 (Wuguang Jia ed., 2013).

85. Liu Jin, On the Quality Control of Criminal Legal Aid [简论刑事辩护质量的控制], in Research on CRiminal Legal Aid, supra note 83, 258-66.

86. Fan \& Ye, supra note 9, at 61-62.

87. Qiuhong Xiong, The International Standards of Effective/Ineffective Defense and Localized Thoughts [有效辩护, 无效辩护的国际标准和本土化思考], 6 C HINA CRIM. SCIENCE [中国刑事法 杂志] 129-35 (2014).

88. Bright \& Sanneh, supra note 5, at 2153.

89. Gideon's Broken Promise, supra note 59, at 24.

90. Justice Denied, supra note 79, at 89.

91. C. Bradley, Criminal Procedure 105 (2d ed. 2007).

92. B. Liebman, Leniency in Chinese Criminal Law?, 33 Berkeley J. InT'L L. 153-222 (2015).

93. H. Packer, Two Models of the Criminal Process, 113 U. PA. L. Rev. 1-68 (1964).

94. Bin Liang, Ni He \& Hong Lu, The Deep Divide in China's Criminal Justice System, 62 Crime L. \& Soc. Change 585-601 (2014).

95. McConville, supra note 26, at 142.

96. Id. at 109-10.

97. Regulations on Lawyers (1980), art. 1.

98. Lawyers Law (1996), art. 2.

99. Hualin Fu, When Lawyers Are Prosecuted: The Struggle of a Profession in Transition, 2 J. Comp. L. 95-132 (2007).

100. Liebman, supra note 92, at 202.

101. Liang, He \& Lu, supra note 94, at 598.

102. Yongzhong Gu, Ning Zuo \& Songbo Wang, Empirical Study on the Legal Aid Provided by Young Lawyers [青年律师刑事辩护实证研究报告], in RESEARCH ON CRIMINAL LEGAL AID, supra note 83, 38-62.

103. MCConvilLe, supra note 26, at 318.

104. Liu \& Halliday, supra note 65 , at 839.

105. J. Rosenzweig et al., Comments on the 2012 Revision of the Chinese Criminal Procedure 
Law, in Comparative Perspectives on Criminal Justice in China 455-503 (M. McConville \& E. Pils eds., 2013).

106. Id. at 495 .

107. Empirical research has revealed that the overwhelming majority of cases charged under Article 306 are baseless. Under this charge prosecution, it also serves as a weapon of the authorities to retaliate against defense lawyers. See Enshen Li, The Li Zhuang Case: Examining the Challenges Facing Criminal Defense Lawyers in China, 24 Colum. J. Asian L. 129-170 (2010).

108. See, e.g., Li Na, Extraordinarily Difficult to Meet Clients in Extraordinarily Significant Bribery Cases [特别重大贿赂案件律师会见尤难], LEGAL DAILY [法制日报], June 21, 2013.

109. Anhui Province Lawyers Association, Report on Three New Difficulties in the Criminal Defense Practice [安徽省刑事辩护新三难调查报告] (2014), available at http://www. ahxblm.cn/display.asp?id=678 (last visited on Jan. 15, 2019).

110. Id.

111. Rosenzweig, supra note 105 , at 502.

112. Chemerinsky, supra note 42 , at 2688.

113. Strickland v. Washington, 466 U.S. 689 (1984).

114. Padilla v. Kentucky, 559 U.S. 370 (2010).

115. T. Zimpleman, The Ineffective Assistance of Counsel Era, 63 S. C. L. Rev. 425-62 (2011).

116. Sui-Lee Wee, China to Adopt Circuit Courts to Reduce Interference, XINHUA News, Dec. 2, 2014, available at https://www.reuters.com/article/us-china-lawmaking/china-to-adoptcircuit-courts-to-reduce-interference-xinhua-idUSKCNOJG10M20141202 (last visited on Jan. 15, 2019).

117. Chemerinsky, supra note 42, at 2693.

118. Suli Zhu, The Party and the Courts, in Judicial Independence in China: Lesson For Global Rule of Law Promotion 52-68 (R. Peerenboom ed., 2009). 